\title{
The Potential Impact of Mass Media Education in the Psycho-Social Life and Epidemiology of Sickle Cell Disease in Nigeria
}

\author{
Samuel Okere ${ }^{1} \&$ Emmanuel Morka $^{1}$ \\ ${ }^{1}$ Department of Mass Communication, Babcock University, Ilishan-Remo, Ogun State, Nigeria \\ Correspondence: Emmanuel Morka, Department of Mass Communication, Babcock University, Ilishan-Remo, \\ Ogun State, Nigeria. E-mail: nenait3@gmail.com
}

Received: July 21, 2020 Accepted: August 19, 2020 Online Published: September 16, 2020

doi:10.5539/gjhs.v12n11p141 URL: https://doi.org/10.5539/gjhs.v12n11p141

\begin{abstract}
The lack of public awareness and education is the greatest challenge in the fight against Sickle Disease (SCD) in Nigeria. The sufferers of the disease experience debilitating pains, psychological challenges, stigmatization and as a result many have very poor social life style. What enduring step, has the mass media, as a reliable societal medium taken to address the spread of SCD? No serious attention has been given to the use of media technology in the education of the masses on the risk factors of SCD. The mass media has a key role to play in the treatment and management of SCD in Nigeria.
\end{abstract}

Keywords: awareness, education, epidemiology, mass media, psychology, Sickle Cell Diseases, social life

\section{Introduction}

Quality education is the greatest investment and mother to sustainable development in any society. Awareness as well; is the beginning and fuel that sustains any developmental initiative (Nnaji, 2020). It is in this context that we express the outcome of this review on the potential impact of mass media education in the psycho-social life and epidemiology of Sickle Cell Disease (SCD) in Nigeria. It is now known that many persons are not aware of the nature of crises and psychological trauma that individuals with SCD experience. Many in this condition who are usually in dear need of kind-hearted and understanding friends to share the burden and pains sometimes do not find even one. They miss a lot of school and social activities during their crisis (Larissa, 2018). Most individuals who have Sickle Cell Disease (SCD) have a very poor social life. This is because of the psychological challenges that the disease pose to carriers. They suffer debilitating pains that are caused by certain physiological conditions like ischemia, hypoxia and ischemic injuries etc (Aziza \& Noah., 2019; Steven, Nahed, \& Troy, 2000). Many suffer various forms of stigmatization because of their health conditions (Coretta \& Cheryl, 2010). A good number of individuals suffer rejection and refusal to participate in various activities in the society because of the disease. The majority of people in the Nigerian society lack awareness and sound education on how to prevent the disease. Sickle Cell Disease is a disease that is caused by the variation in a single gene. It is the most occurring monogenic disorder that has affected millions of humans in the world (Elizabeth, Donald, Smruti, Cathleen, Mei, Daies, \& Igor, 2018). The striking inheritance pattern of the disease as an autosomal recessive disease (both parents are carriers of the gene) is a key factor to its persistence in any population (Alex et al., 2018). The mass media is a major tool in any modern society for the dissemination of information. The public trust on the mass media has empowered them to detect what is important to the modern society through various media activities such as information dissemination, mobilization, advertisement, publicity, education and entertainment etc (Ikachoi, 2012). Since research has shown that Nigeria bears the highest burden of the disease (World Health Organisation [WHO], 2006; Jiya, Umar, Ibrahim, Mohammed, Erhabor, Mainasara, Ndakotsu, Garba, \& Musa, 2017; Emechebe, Onyire, Orji, \& Achigbu, 2017; Adewoyin, Alagba, Adedokun, \& Idubor, 2015; Allege, 2015), one could decide to ask the following questions.

What enduring step, has the mass media, as a reliable societal medium taken to address the psycho-social epidemiology of this disease?

What can education through the mass media contribute to improving the psychology and social life of the affected population? 


\section{Awareness and Epidemiology of Sickle Cell Disease}

The lack of public awareness and education is the greatest challenge in the fight against Sickle Cell Disease (Alan, Clinton, Lleniece, \& Edmund, 1979). Despite the high morbidity and mortality, very little attention has been given by the media, government and the general public to the behaviours and conditions that expose people to SCD when compared to the intervention programs that have been implemented to eradicate HIV/AID, malaria in Nigeria and Covid-19 etc (Baba, Yvonne, Juliana, John, Claire, Sukhleen, \& Stephen, 2015; Hamad, Nedal, Asmaa, Mohammad, Amin, \& Hani, 2020; Ahmed, 2020).

Globally, SCD has been traced to individuals with ancestral linage from sub-Saharan Africa, India, Saudi Arabia and Mediterranean countries. Therefore prevalence is higher among individuals who hailed from such geographical location (Aziza \& Noah, 2019). There is a substantial level of variation in the birth incidence of SCD in the world. The frequency of carriers' state is directly proportional to the incidence of the disease at birth (WHO, 2006). Due to factors associated with immigration and emigration, many countries have recorded incidence of the disease. The incidence, distribution and challenges associated with the control of the disease have given it a global concern (Kolade, Kevin, Emmanuel, \& Mofoluke, 2018; Evelyne, Rim, Mohamed, Ahmad, Hussein, \& Adlettle, 2014).

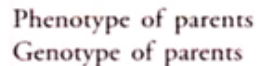

Genotype of parents

Gametes

Offspring genotype

Offspring phenotype
Sickle cell anaemia carrier $\mathrm{Hb}^{A} \mathrm{Hb}^{5}$

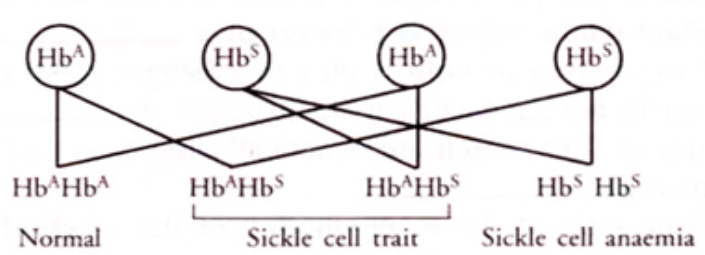

Figure 1. An illustration of the transfer of sickle cell trait from parents to offspring.

Source: (http://www.biotechnologynotes.com/genetics/pleiotropy/definition-of-pleiotropy-with-diagram-geneticsbiotechnology/13432)

Besides migration, the natural protection in individuals with heterozygous allelic pair for the sickle cell against malaria is also closely linked to the global distribution of the disease. In the year 2010, about 305,000 births were carriers of this genetic disorder (Elizabeth et al., 2018). In the United States of America, the ratio of SCD 1:500 African Americans and about 100,000 in the entire country (Aziza \& Noah, 2019). Each year more than 2/3 of 300,000 newborns with haemoglobin disorder in the world are carriers. The burden of the disease in Sub-Saharan Africa is higher than in other regions of the continent with Nigeria as the highest (WHO, 2006; Kolade, Kevin, Emmanuel, \& Mofoluke, 2018). 2\% of all children are born with the condition in some areas of Sub-Saharan Africa and $10-40 \%$ of the populations are healthy carriers who have inherited the trait from a single parent. It is about $1-2 \%$ in the North Africa coast and $<1 \%$ in South Africa. About 150,000 individuals are born with the disease every year. 20 out of every 1000 birth are carriers of the disease in Nigeria. The frequency of the trait is within $20-30 \%$ of the entire population in Ghana and Nigeria. Northern Tanzania has also recorded a very high prevalence rate of $21.1 \%$ birth with the disease in recent times. A study in Morocco revealed that the most common haemoglobinopathy is SCD. $23 \%$ of the population in the pediatric ward had homozygous $\mathrm{HbSS}$ and $43.5 \%$ have sickle cell gene. The finding from a cohort study in Kenya also revealed that $69.3 \%$ of children admitted sickle cell patients were undiagnosed (Lizette, Ayodeji, \& Jennifer, 2019).

In "An assessment of knowledge, awareness, and attitude of undergraduates toward sickle cell disease in Lagos, Nigeria" Ebele, Olusola, Benjamin, Ayobami, Akisegun, Adedoyin, and Abdulhafeez, (2017) disclosed that through the mass media, lectures and seminars, about $92.5 \%$ of undergraduate campus students have gained an appreciable level of awareness and knowledge of the disease. However, according to Grace (2018), the awareness of this disease among campus population may not guarantee the awareness among the general public who are not exposed to these educative opportunities as the knowledge of the disease is not vast among the general public. Individuals who are within rural communities and those that are bound by cultural and religious practices may not be properly informed about the disease. It is also understood that there exist unrealistic myths and misconceptions about the disease even among some urban dwellers (Mohammed, Raijaa, Muna, Robin, \& Anil, 2016; Sharifu, Utah, Bashir, John, Sylvia, \& Alimah, 2018; Yvette, 2015; Ajilore, Onyenankeya, Morka, Akoja, Akintayo, \& 
Ojomo, 2018; Ugwu, 2016).

\section{The Position of the Mass Media in Providing Education on the Risk Factors of SCD}

Education through mass media refers to passing educative information through media technology to reach a large audience. The use of electronic media such as television, radio, film, movies, DVDs, CDs, Camera, video etc is very effective in the education of the public. However, for effective mass communication and education of the public on this disease, all mass media devices need to be deployed to reach the masses either by writing, broadcast, acting, advertising etc (http://ajeshpk.blogspot.com/2015/10/media-introduction-media-refers.html). Because the majority of people in Nigeria for reasons such as religion, rural localities, tradition, cultural practices, ignorance etc are yet to have a detailed understanding of the risk factors of the disease. It is very necessary that the masses need to be properly educated on the risk factors of the sickle cell disease before any meaningful achievement towards the reduction of the burden of the disease can be made (Mohammed, Raijaa, Muna, Robin, \& Anil, 2016; Sharifu, Utah, Bashir, John, Sylvia, \& Alimah, 2018; Yvette, 2015; Ajilore, Onyenankeya, Morka, Akoja, Akintayo, \& Ojomo, 2018; Ugwu, 2016).

The Risk factors of SCD are those behaviours, characteristics or conditions that increase the chances and likelihood of inheriting or deteriorating the disease condition in an individual. (www.eupati.eu/pharmacoepidemiology/risk- factors-health-disease/\#Behavioural_risk_factors).

At this point, it is necessary to state that educating the public through the mass media cannot be graded successfully until every relationship with foresight of marriage to begins considers the priority of genotypic compatibility before letting the fire of emotion and love to burn. It is quite imperative to access the compatibility of your genotype and any prospective partner before you say yes to an individual you intend to marry. This intervening concept in a relationship is very much different from phenotypic description or acceptability. An individual can be phenotypically compatible but genotypically incompatible (www.aun.edu.ng/index.php/campuslife/health-center/health-tips/genotype-compatibility).

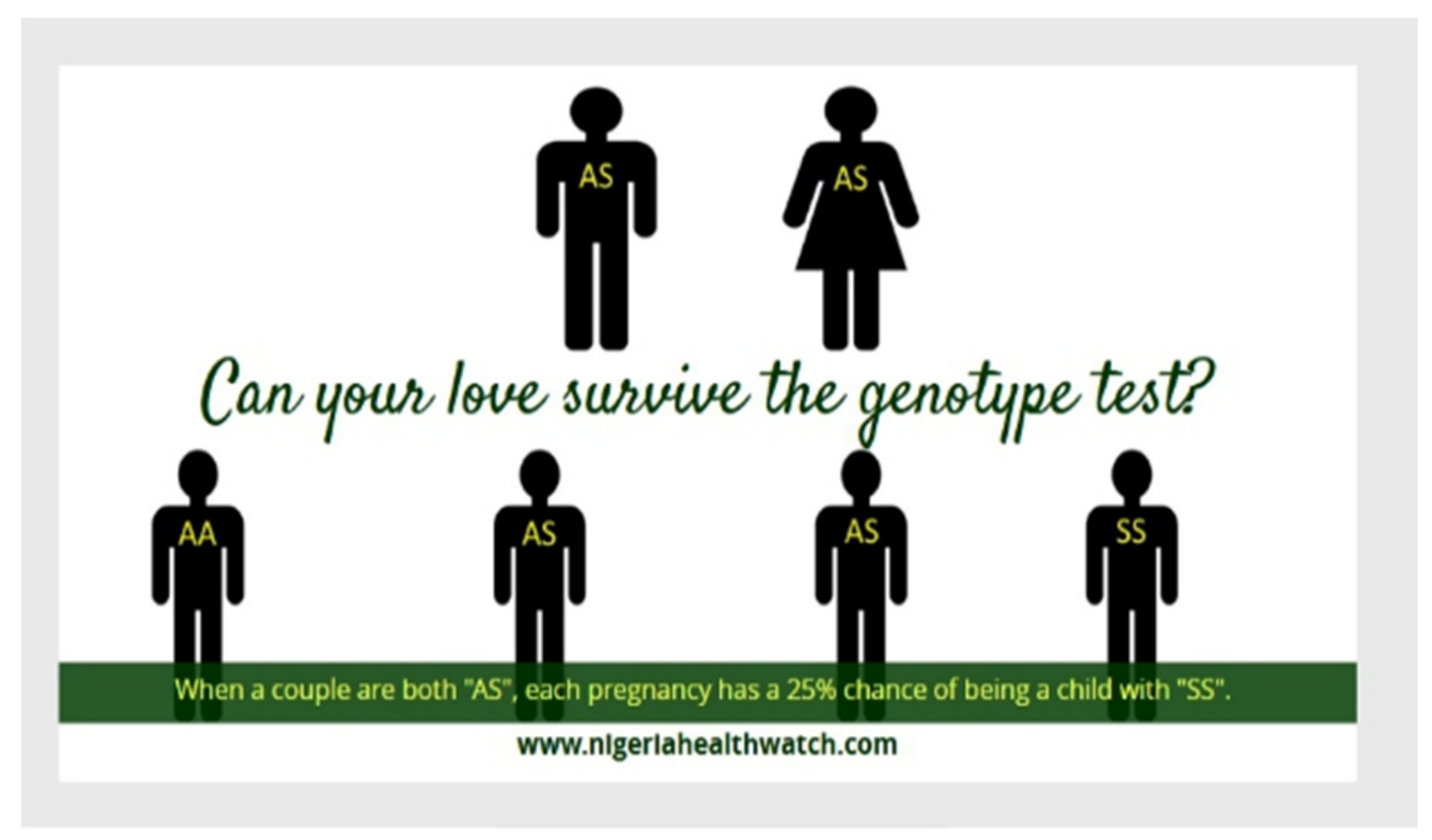

Figure 2. Pictorial illustration for genotype compatibility in a relationship

On a more general term, risk factors are expressed as behavioral, physiological, demographic, environmental and genetic risk factors. They are represented individually although they do not exist in that way in practice.

Source: (www.eupati.eu/pharmacoepidemiology/risk-factors-health-disease/\#Behavioural_risk_factors). 


\subsection{Genetic Risk Factor}

Medical experts in their research have disclosed that differences among individuals occur due to the variation in the regulatory sequence of the order of gene expression (Robert, 2006). Sickle cell disease is genetic. It is passed from parent to the offspring through the bloodline.

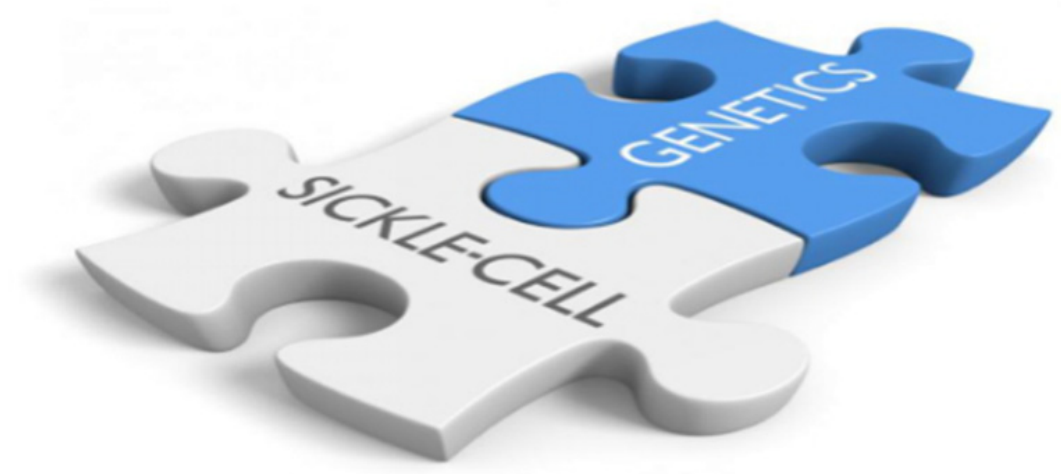

Figure 3. An illustration showing that sickle cell disease is genetic

Source: Yvette, B. (2015).

Individuals can have only one sickle cell gene and not suffer any disorder themselves. Children from such parents who have this single gene in them stand the risk of procreating children who will have the disorder if their partners are also carriers (Jon, 2017) (see Figure 1). Intending partners who are recessive carriers of the gene should be discouraged from going to any relationship that will result in procreation. Negligence to this fact is a key factor to its persistence of the disease in any population (Alex et al., 2018).

There are basic indispensable molecular caused by the disease that is traceable to the gene of individuals (Robert, 2006). The disease describes a group of haemoglobin disorders that is characterized with the presence of one haemoglobin "S" ( $\mathrm{Hb} \mathrm{S})$ allele, $\beta$-globin gene and another variant allele or $\beta$-thalassemia which reduces the production of $\mathrm{Hb} \mathrm{A}$ (the normal haemoglobin). The level of $\mathrm{HbA}$ produced can result in multiple mutations of $\beta$-thalassemia. People with $\mathrm{HbS}$ and $\beta$-thalassemia allele are classified as either $\mathrm{Hb} \mathrm{S} / \beta^{+}$-thalassemia or $\mathrm{Hb} \mathrm{S/}$ $\beta^{0}$-thalassemia; all dependent on the level of $\mathrm{Hb}$ A produced. Those with homozygous sickle cell allele (Hb SS) and $\mathrm{Hb} \mathrm{S} / \beta^{0}$-thalassemia are referred to as sickle cell anaemia.Hb SS carriers are relatively prone to more disease symptoms followed by $\mathrm{Hb} \mathrm{S} / \beta^{0}$-thalassemia while $\mathrm{Hb} \mathrm{S} / \beta^{+}$-thalassemia or $\mathrm{Hb} \mathrm{C}$ experience a milder or moderate disease symptoms (Mark, Scott, \& Roshni, 2011; John \& Chide, 2017 ).

\subsection{Behavioural Risk Factors}

Children with the disease have an increased risk of developing neurodevelopmental disorders. This disorder may take the form of attention deficit hypersensitivity (Oliver, Mira, \& Hanna, 2019), intellectual disability and specific learning disabilities (Eboni, Anne, Michael, James, \& Bruce, 2015). In cases of attention deficit hypersensitivity, it is common in most children and some adults. Such individuals may find it difficult to pay attention to details, always involved in excessive talking, have difficulty in organizing tasks and activities, fidgeting and difficulty to remain seated in an appropriate position (Gabriele, Annalaura, Agustin, Marco, Agustin, Lorenzo, \& María, 2019). Individuals with this disease are at risk of facing some disability challenges. This challenge could be in the form of intellectual disability and specific learning disabilities as earlier mentioned. In such a condition, the patient usually experiences a high level of restrictions due to physiological impairment. He/she is forced to restrict involvement in activities or some forms of social participation (Mark, Scott, \& Roshni, 2011). The disabilities experienced by patients are usually mediated by several etiological mechanisms such as vaso-occlusion crisis, organ dysfunction, depression, impairment of vision and/or hearing, bone disease, anaemia, skin ulceration, pulmonary complications etc. The various episodes of pains hinder participation in activities with others while in school. Other activities of daily living and individual's social event of interest are hindered as well. The report that depressed patients also experience more days of pains is also in agreement with the experiences of individuals that are suffering from other chronic diseases like cancer etc (John \& Chide, 2017; Mark, Scott, \& Roshni, 2011).

\subsection{Physiological Risk Factors}

People who have SCD are easily tired, dizzy and even out of breath. This experience is associated with the 
physiological risk factors of SCD (Larissa, 2018). An individual with the disease has a sickle-like shaped erythrocyte (Red Blood Cell) instead of the normal erythrocyte. This deformation causes difficulty in the movement of blood within the blood vessels and a reduction in the amount of required oxygen to the rest parts of the body (http://oncofertility.northwestern.edu/resources/sickle-cell-anemia).
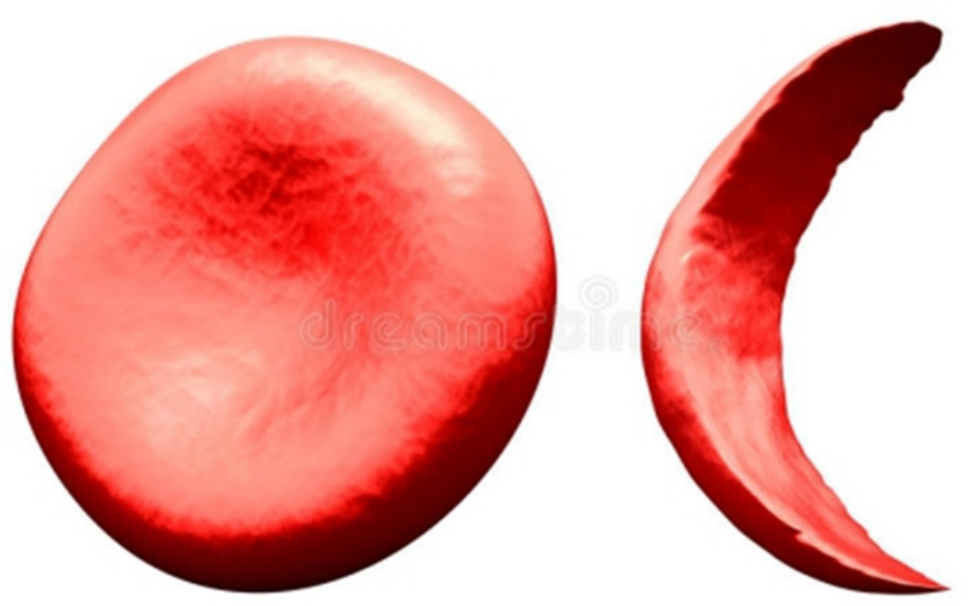

Figure 4. An illustration of differences in the morphology of a normal shaped erythrocyte and a Sickle-shaped erythrocyte

Source: (https://www.dreamstime.com/stock-illustration-normal-vs-sickle-red-blood-cell-human-image44305089)

Sickle erythrocytes are largely occasioned by changes in potassium and water efflux mediated by potassium-chloride co-transport and Gardos channels. This physiological condition triggers injury to the local area of the body where there was an absence of enough oxygen in the tissue (Aziza \& Noah, 2019).

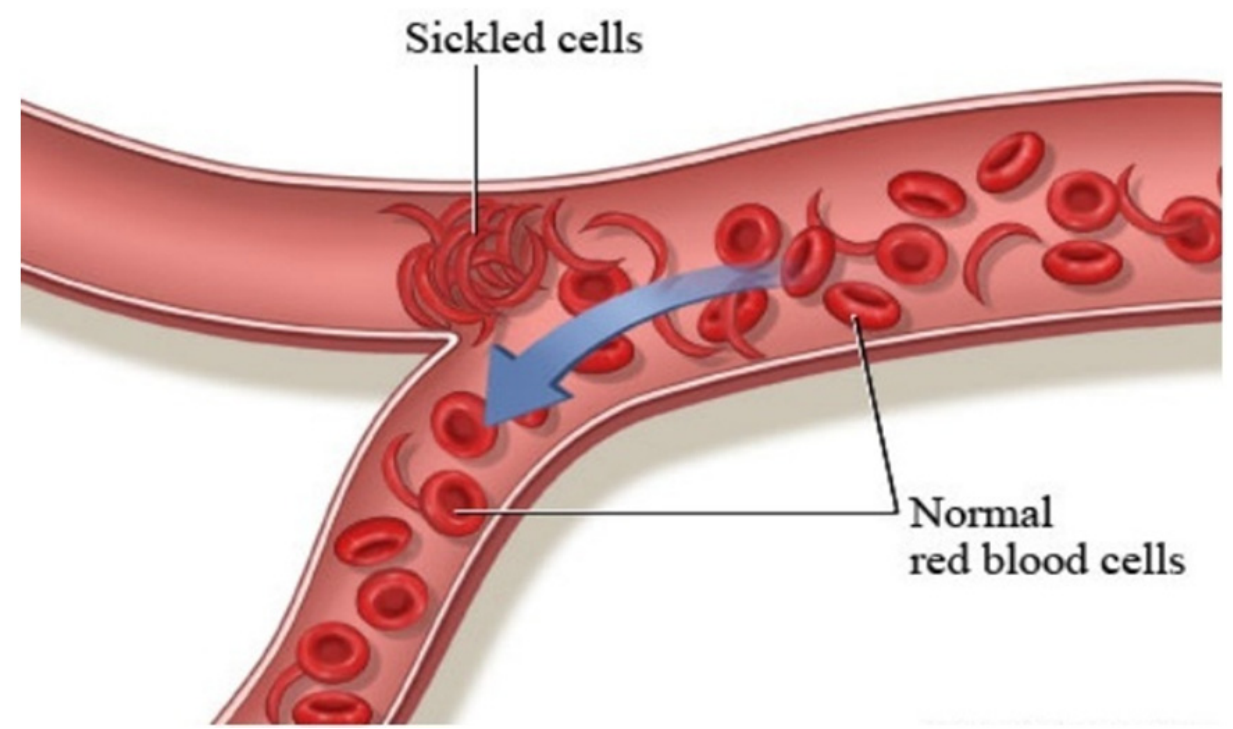

Figure 5. An illustration of small vessel occlusion caused by an increase in adhesion of erythrocytes, the formation of heterocellular aggregates and hypoxia in the blood vessel of a sickle cell disease patient

Source: (http://oncofertility.northwestern.edu/resources/sickle-cell-anemia)

\section{Factors Contributing toPsyco-Social Challenges and Stigmatazation of Individuals with SCD}

Individuals with SCD suffer numerous social challenges and stigma that affects their psychology. Poor quality of 
health, fatigue, exhaustion, deprivation and stigma while managing the disease all contribute to deformed psychology and social life of individuals (Robin, Linda, \& Victoria, 2018).

\subsection{Poor Quality of Health Compared to Other Adults That Are Living with Other Chronic Diseases}

The crisis causes several complications with the susceptibility of damaging the brain, lungs and even the spleen at an early age. When compared to other chronic diseases, adults with SCD suffer a lower quality of health (National Heart, Lung, and Blood Institute, 2008; Steinberg, 1998; Robin, Linda, \& Victoria, 2018). A ten years research on the Prevalence and pattern of sickle cell disease among children attending tertiary and non-tertiary health care institution in South-Eastern State, Nigeria, reported that $87.6 \%$ of individuals with the disease had a fever, $45 \%$ had pains in the bone with general body weakness. Jaundice was the most common clinical symptom accounting for $59.8 \%$ followed by pallor $(51.1 \%)$. It was observed that infection $(50.3 \%)$ was the highest clinical complication that occurred in patients, besides $36 \%$ of vaso-occlusive crises (Kevin et al., 2016).

It is imperative to say that the history and physical examination of individuals with the disease fall within the ranges of being asymptomatic to a level of presenting a wide range of symptoms. Sickle cell disease patients are usually asymptomatic during their first six month of birth due to the presence of fetal haemoglobin. However, with the decrease of fetal haemoglobin, they begin to show symptoms (Aziza \& Noah, 2019). Regardless of the genetic identity at the site of haemoglobin mutation, there is a significant difference in the rate at which sickle cell patients are infected. The severity of symptom experienced also varies among individuals living with this disease. Some experience chronic pains or fatigue while others have occasional acute pains (National Heart, Lung, and Blood Institute, 2008; Steinberg, 1998).

Due to asplenia and immunocompromised state of SCD patients, they stand the chance of being vulnerable to infection more especially by encapsulated organisms. The use of penicillin prophylaxis and the pneumococcal vaccine has tremendously abated the incidence of bacterial infection in many places (Elizabeth, Donald, Smruti, Kathleen, Mei, Daies, \& Igor, 2018; Aziza \& Noah, 2019). Infection in patients provokes some pathophysiological changes that make them go through severe pains. Twenty years of cohort studies on SCD revealed that it is a major cause of high mortality rate more especially among children within this condition (Catherine, Babalnusa, \& Stephen, 2010).

\subsection{Vaso-Occlusive Crisis (VOC)}

VOC is the major cause of acute pain in individuals with SCD. It is a physiological challenge that occurs when there is an obstruction in the blood vessel by a sickled red blood cell. This obstruction causes ischemia, hypoxia and ischemic injuries. Patients pass through debilitating pains in the local site of occurrence. This pain occurs mostly in the back, long bones, pelvic, abdomen and chest regions of the body. As early as six months of age although more frequent in adolescents and adults, an SCD individual may begin to experience this symptom with accompanied swelling of both hands and feet (Aziza \& Noah, 2019; Steven, Nahed, \& Troy, 2000). VOC is the major cause of clinical complications like stroke, pain syndrome, leg ulcer, spontaneous abortion and renal insufficiency among carriers. Severe bone pain associated with microvascular occlusion is one of the common reasons while SCD individuals are rushed to emergency and hospitalization (Steven, Nahed, \& Troy, 2000).

Records have shown that $5.2 \%$ of SCD patients usually experience three to ten severe pain episodes every year. Each episode usually lasts for five to seven days except in severe cases where pains may last for up to weeks or even months. In cases of the later (i.e when pains persist for more than seven days), the source of bone pain may be reasons such as osteomyelitis, avascular necrosis and compression deformities. Individuals with homozygous sickle cell and sickle celled- $\beta^{\circ}$-thalassemia usually experience higher VOC than other carriers with haemoglobin $\mathrm{SC}$ and sickle celled- $\beta^{+}$-thalassemia genotype. It has also been found that the psychology and cultural background of individuals influences their perception of pain (Sharifu, Rtah, Bashir, John, Sylvia, \& Alimah, 2018; Steven, Nahed, \& Troy, 2000).

\section{The Role of the Media in the Treatment and Management of SCD}

The public trusts the mass media is to detect what is important to their society. It is expected that the mass media will disseminate useful and healthy information. It is on this note that we expect the mass media will also provide the available treatments and best management practice for the disease to the knowledge of the masses. The mass media as an educative platform is expected to promote health programs, provide charge waivers and encourage the education of the public on the burden of this disease considering the fact that Nigeria has the highest burden of the disease in the world (Kevinet al., 2016; Baba et al., 2015). The cost of maintaining a healthy life is very expensive due to reoccurring debilitating health issues coupled with the shortened life expectancy (National Heart, Lung, and Blood Institute, 2008). Therefore, Health NGO(s), local and international bodies should step up to the media to 
seek the help of media experts in sensitization and creating awareness of the opportunities available for SCD persons.

\subsection{Mass Media Sensitization and Awareness Campaign on Premarital, Prenatal and Genetic Counselling}

The importance of prenatal and genetic counseling as a measure for prevention and intervention on SCD cannot be over emphasized. It is in this regards that the WHO recommended creation of certain remedial centers to serve as a contributory factor to curb the proliferation of wrong decision that lead to the birth of individual with the disease (Ebele et al., 2017). Awareness on the need for a positive genotype compatibility test should be promoted. The mass media should educate the masses on the importance of understanding that feelings, emotions or erotic love in a relationship should not be considered at the expense of a positive genotype compatibility test (www.aun.edu.ng/index.php/campus-life/health-center/health-tips/genotype-compatibility). Carrier detection test and counseling centers recommended by WHO to various regions of the country for combating SCD should be brought to the knowledge of the public through the mass media (Ebele et al., 2017). It was also recommended that such centres must be adequately staffed with trained resource manpower to achieve the real essence of establishing them (Adewoyin, Alagbe, Adedoun, \& Idubor, 2015).

\subsection{Sensitization and Awareness on the Synergistic Effect of Combined Professional Therapy}

The mass media should educate the masses on the advantage of early diagnosis as practised in developed nations like the USA and other European nations. This practice will contribute to the management of SCD in Nigeria as the disease has limited curative measures. Potential mothers with the tendency of conceiving individuals with the disease should be enlightened through the television, radio, movies and other mass media technological platforms on the necessity for antenatal testing and neonatal screening which are appropriate for early diagnosis and management of the disease. In Greek Cyprus and Greece, preconception screening has yielded some level of success (Baba et al., 2015; National Heart, Lung, and Blood Institute, 2008). Opportunities like the blood and marrow stem transplant or gene therapy should be brought to the knowledge of the public. As the popular English adage, "applied knowledge is power" there is an urgent need for community sensitization and education on the disease. An exchange transfusion may be necessary to abort cycle in cases when Vaso-Occular crisis becomes recurrent and lasts for weeks. (Steven, Nahed, \& Troy, 2000).

Many acknowledge the approach of drug therapy in the management of SCD. However very many are yet to understand the futility of drug therapy without psychological support. The media can serve as a means of providing psychological support and also promoting drug therapy with psychological support. Most treatments are within the ranges of adequate hydration, ophoid analgesics, adequate rest and cognitive and behavioural therapies. To obtain optimal management requirements for SCD individuals, there is a need for a multidisciplinary team made up of a physician, haematologist, nurses, psychiatrist, physical therapist, a pain specialist and a social worker. To prevent the development of chronic pain syndrome and psychological instability, a patient must be frequently engaged in discussions of how he/she will cope with the circumstance and reassurance about the management of the pain (Steven, Nahed, \& Troy, 2000).

\subsection{Media Advocacy for Special Attention to SCD Patients}

There should be advocacy programs for special attention and exclusion of SCD persons in regular treatment rules of administering drugs. This is because it is understood by medical practitioners that the most potent pain-relieving drugs are narcotics. However, because of the risk of addiction and loss of efficacy associated with prolong use many doctors who use them are careful in prescribing them for their patients. This ought not to be associated with the treatment of SCD patients because the report of addiction is not higher than $3 \%$. The resultant effect of such reservation is that pain associated with VOC is often undertreated (https://www.addictioncenter.com/opiates/; https://www.emedicinehealth.com/narcotic_abuse/article_em.htm; Cynthia, Nitya, Diana, \& Lakshmanan, 2019; Steven, Nahed, \& Troy, 2000). Never the less, there are other drugs which are effective in the treatment of acute pains in patients. Physicians are encouraged to follow the three-step analgesic ladder recommended by the World Health Organization. Oral fluids and non-narcotic analgesics can be used in the treatment of patients with mild pains at home while narcotic analgesics can be used for treatments of moderate and severe pain in patients(Steven, Nahed, \& Troy, 2000; Cynthia, Nitya, Diana, \& Lakshmanan, 2019).

\subsection{Promoting Awareness and Advocating for Subsidizing of Treatment Opportunities}

Another approach to the treatment of the disease is a bone marrow transplant. This process is highly sophisticated and demands well-trained doctor or experts (Euzebus, Puline, \& David, 2019). It is an expensive method therefore only very few individuals who suffer from the disease can afford it. This situation is very much peculiar to those in Sub- Saharan Africa where many carriers are grossly poor and are financially precarious (Bruno, 2012). For 
instance, in Nigeria, the University of Benin Teaching Hospital recorded the first bone marrow transplantation (Euzebus, Puline, \& David, 2019). Preventive methods such as Pre-natal diagnosis and termination of affected pregnancies have been an approach to preventing the birth of any SCD carrier. Although this approach is not popularly welcomed for religious and ethical reasons (Euzebus, Puline, \& David, 2019), the media has a great role to play in the advocacy for subsidizing the cost for treatment by the eligible bodies and the enlightenment of the public on the opportunities.

\section{Conclusion and Recommendation}

\subsection{Conclusion}

Several studies have proven that there are variations in the prevalence, awareness, knowledge and attitude towards sickle cell disease (SCD) across various regions in the world. Premium Times (2018) reported that the disease has remained endemic in Nigeria because of lack of awareness, lack of funds and absence of good government policies geared towards addressing the prevalence of the disease. However, some empirical studies have shown that general attitudinal disposition by individuals and government, means of SCD communication intervention, the influence of finance and religious beliefs in the pre-marital decision are major factors that have contributed in the persistence of the disease in sub-Saharan Africa and more especially Nigeria (Makani, Williams, \& Marsh 2017; Jiya et al., 2017; Patrick, Mc Gann. Ariell, Hermandez, \& Russal, 2018; Emechebe, Onyire, Orji, \& Achigbu, 2017).

\subsection{Recommendation}

The mass media to be effective in the control of the proliferation, and improvement of the psychology and social lifestyle of SCD in the Nigerian society the campaign and intervention programs should be organized and backed up with serious implementation as it was done to fight diseases like HIV/AID, polio, malaria and even the current Covid-19 pandemic in Nigeria (Hamad, Nedal, Asmaa, Mohammad, Amin, \& Hani 2020; Ahmed, 2020; Baba, Yvonne, Juliana, John, Claire, Sukhleen, \& Stephen, 2015). All electronic media such as television, radio, film, movies, DVDs, CDs, Camera, video etc must be deployed in the education of the public on prevention, treatment and management of the disease. All intending couples and sexually active relationships must be made to know and understand the importance of a positive genotype compatibility test (www.aun.edu.ng/index.php/campuslife/health-center/health-tips/genotype-compatibility). Owners of media houses and stations should sponsor an advocacy or media campaign program for the government, international bodies, etc to assist in the subsidizing of born marrow transplant to an affordable cost. This will enable the masses to access such treatment opportunity since a majority of citizen fall within the low-income category (Euzebus, Puline, \& David, 2019; Elizabeth, Donald, Smruti, Kathleen, Mei, Daies, \& Igor, 2018).The mass media should liaise with doctors in the campaign for improvement in the health sector. The aftermath of such effort can yield employment of sufficient experts hence; a multidisciplinary team made up of a physician, haematologist, nurses, psychiatrist, physical therapist, a pain specialist and a social worker could be available to attend to patients with SCD (Cynthia, Nitya, Diana, \& Lakshmanan, 2019; Steven, Nahed, \& Troy, 2000).

\section{Competing Interests Statement}

The authors declare that there are no competing or potential conflicts of interest.

\section{References}

Adewoyin, A. S., Alagbe, A. E., Adedoun, B. O., \& Idubor, N. T. (2015). Knowledge, Attitude And Control Practices Of Sickle Cell Disease Among Youth Corps Members In Benin City, Nigeria. Annals of Ibadan Postgraduate Medicine, 13(2), 100-107.

Ahmed, N. (2020). Estimation of COVID-19 burden in Egypt. The Lancet Infectious Diseases. https://doi.org/10.1016/S1473-3099(20)30329-7

Alan, B. C., Clinton, M., Lleniece, L., \& Edmund, M. (1979). A Study of Media Effectiveness for Sickle Cell Anemia Education in a Rural Community. Journal of the national medical association, 71(11), 1055-7.

Alex, W. M., George, M., Sophie, U., Carolyne, M. N., Gideon, N., Johnstone, M., ... Thomas, N. W. (2017). The clinical epidemiology of sickle cell anemia in Africa. American Journal of Hematology, 93(3), 363-370. https://doi.org/10.1002/ajh.24986

Aziza, S., \& Noah, P. K. (2019). Sickle cell disease. Treasure Island (FL): StatPearls Publishing. Retrieved from https://www.ncbi.nlm.nih.gov/books/NBK482384/

Baba, P. I., Yvonne, D., Juliana, O. L., John, D., Claire, E. M., Sukhleen, M. S., \& Stephen, K. O. (2015). Sickle Cell Disease Screening in Northern Nigeria: The Co-Existence of BThalassemia Inheritance. Pediatrics \& 
Therapeutics, 5(3), 1-4. https://doi.org/10.4172/2161-0665.1000262

Bruno, F. C. (2012). Quality of life of individuals with sickle cell disease followed at referral centers in Alagoas, Brazil. RevistaBrasileilra de Hematologia e Hemoterapia, $34,6$. https://doi.org/10.5581/1516-8484.20120110

Catherine, B., Babalnusa, S., \& Stephen, K. O. (2010). Infection in Sickle Cell Disease: A review. International Journal of Infectious Diseases, 14(1), e2-212. https://doi.org/10.1016/j.ijid.2009.03.010

Coretta, M. J., \& Cheryl, B. (2010). Health-Related Stigma in Young Adults With Sickle Cell Disease. Journal of the National Medical Association, 102(11), 1050-1055. https://doi.org/10.1016/S0027-9684(15)30732-X

Cynthia, B. S., Nitya, B., Diana, R., \& Lakshmanan, K. (2019). Management of Chronic Pain in Adults Living With Sickle Cell Disease in the Era of the Opioid Epidemic A Qualitative Study. JAMA Network Open, 2(5), e194410. https://doi.org/10.1001/jamanetworkopen.2019.4410

Ebele, U., Olusola, O., Benjamin, A., Ayobami, I., Akisegun, A., Adedoyin, D., \& Abdulhafeez, B. (2017).An assessment of knowledge, awareness, and attitude of undergraduates toward sickle cell disease in Lagos, Nigeria. Nigerian Medical Journal, 58(6), 167-172. https://doi.org/10.4103/nmj.NMJ_111_18

Eboni, I. L., Anne, M. C., Michael, V. J., James, F. C., \& Bruce, K. S. (2015). Risk factors for attention and behavioral issues in pediatric sickle cell disease. Journal of clinical pediatrics, 54(11), 1087-1093. https://doi.org/10.1177/0009922815594356

Elizabeth, W., Donald, W., Smruti, P., athleen, M., Mei, Y. G., Daies, A., \& Igor, R. (2018). The global burden of sickle cell disease in Children under five years of age: a systematic reiew and meta-analysis. Journal of Global Health, 8(2), 021103. https://doi.org/10.7189/jogh.08.021103

Emechebe, G. O., Onyire, N. B., Orji, M. L., \& Achigbu, K. I. (2017). Sickle Cell Disease In Nigeria- A Preview. Journal of Dental and Medical Sciences, 16(1), 87-94. https://doi.org/10.9790/0853-1601048794

Euzebus, C. E., Puline, E. O., \& David, W. (2019). Ethical issues in denial of church wedding based on couple's hemoglobin genotype in Enugu, south eastern Nigeria. BMC Med Ethics, 20, 37. https://doi.org/10.1186/s12910-019-0376-8

Evelyne, K., Rim, H., Mohamed, B., Ahmad, S., Hussein, A. A., \& Adlettle, I. (2014). Incidence of Sickle cell Disease and other Hemoglobin ariant in 10,095 lebanese Neonates. Plos One, 9(9), e 105109. https://doi.org/10.1371/journal.pone.0105109

Gabriele, D., Annalaura, C., Agustin, L. G., Marco, V., Agustin, L. M., Lorenzo, C., \& María, M. S.V. (2019). International Journal of Environmental Research and Public Health Review The Association between Lead and Attention-Deficit/Hyperactivity Disorder: A Systematic Review. International Journal of Environmental Research and Public Health, 16, 2-14. https://doi.org/10.3390/ijerph16030382

Grace, A. (2018). Exploring the Role of Religious Leaders in Preventing Sickle Cell Disease in Nigeria. A Walden Dissertations and Doctoral Studies Collection (pp. 74-117).

Hamad, M. A., Nedal, A., Asmaa, M. A., Mohammad, A., Amin, A., \& Hani, M. A. (2020). COVID-19 Knowledge, Attitude and Practice among Medical and Non-Medical University Students in Jordan. Journal of Pure and Applied Microbiology, 14(1), 17-24. https://doi.org/10.22207/JPAM.14.1.04

http://oncofertility.northwestern.edu/resources/sickle-cell-anemia accessed 30/08/2019

http://www.biotechnologynotes.com/genetics/pleiotropy/definition-of-pleiotropy-with-diagram-geneticsbiotechnology/13432 accessed 30/08/2019

https://www.addictioncenter.com/opiates/ accessed 26/07/2019

https://www.aun.edu.ng/index.php/campus-life/health-center/health-tips/genotype-compatibility accessed 08/10/2019

https://www.dreamstime.com/stock-illustration-normal-vs-sickle-red-blood-cell-human-image44305089 accessed 30/08/2019

https://www.eupati.eu/pharmacoepidemiology/risk-factors-health-disease/\#Behavioural_risk_factors accessed 27/07/2019

Jiya, N. M., Umar, A., Ibrahim, K. K., Mohammed, K., Erhabor, O., Mainasara, A. A., .. \& Musa, A. O. (2017).Sickle cell anemia: A study of prevalence among children attending Usmanu Dan Fodiyo University Teaching Hospital, Sokoto, North-Western Nigeria. American journal of medicine, 2(2), 1-8. https://doi.org/10.9734/AJMAH/2017/30287 
John, C.A., \& Chide, E. O. (2017). Comorbid depression in sickle cell disease: An overview of determinants and need for early detection. Sudan Medical Monitor, 12(2), 66-73. https://doi: 10.4103/summ.summ_11_17

Jon, J. (2017). Sickle cell disease: Overview, symptoms, and causes. Medical News Today.Retrieved from https://www.medicalnewstoday.com/articles/315801.php\#Causes\%20and\%20prevalence

Kevin, C. D., Anthony, C. I., Kenechi, U., Chukwuma B. D., Irene, M., Tope, B.O., ... Ikechi, O. (2016). Prevalence and pattern of sickle cell disease among children attending tertiary and non-tertiary health care institution in South Eastern State, Nigeria: A 10 year survey. Journal of research in medical and dental science, 4(3), 75-81. https://doi.org/10.5455/jrmds.2016432

Kolade, A., Kevin, O., Emmanuel, M., \& Mofoluke, A. (2018). Demography as a Determinant of Awareness, Knowledge and Attitude of Asaba Youth to Media Advocacy Campaign on Sickle Cell Disorder. Global Journal of Health Science, 10(11), 19-27. https://doi.org/10.5539/gjhs.v10n11p19

Larissa, E. (2018). My friend has sickle cell disease. How can I help? Retrieved June 29, 2020, from, https://kidshealth.org/en/teens/sickle-cell- friend.html

Lizette, M., Ayodeji, A., \& Jennifer, K. M. (2019). Knowledge, beliefs and practices regarding sickle cell eye disease of patients at the sickle cell unit.Jamaica The Pan African Medical Journal, 32, 84. https://doi.org/10.11604/pamj.2019.32.84.14742

Makani, J., Williams, T. N., \& Marsh, K. (2017). Sickle Cell Disease in Africa: Burden of Research Priority. US national library of medicine. 101. https://www.ncbi.nlm

Mark, E. S., Scott, D. G., \& Roshni, K. (2011). Disability among individuals with sickle cell disease. American Journal of preventive medicine, 41(6), S390 - S397. https://doi.org/10.1016/j.amepre.2011.09.006

Mohammed, H. A., Raijaa, A., Muna, A., Robin, D., \& Anil, C. M. (2016). Knowledge and Health Beliefs Regarding Sickle Cell Disease Among Omanis in a Primary Healthcare Setting: Cross-sectional study. Sultan Qaboos University Medical Journal, 16(4), e437-e444. https://doi.org/10.18295/squmj.2016.16.04.006

National Heart, Lung, and Blood Institute. (2008). Sickle cell anemia.Diseases and Conditions Index. Retrieved from. http://www.nhlbi.nih.gov/health/dci/Diseases/Sca/SCA_WhoIsAtRisk.html

Nnaji, P. T. (2020). Application to the Africa Investment Gate Way Group (AIGG) for sponsorship. Retrieved from https://www.aiggl.org/

Oliver, H., Mira, L. C., \& Hanna, C. (2019). Emotion dysregulation subgroups in patients with adult AttentionDeficit/Hyperactivity Disorder (ADHD): a cluster analytic approach. Scientific Reports, 5639. Retrieved from https://www.nature.com/articles/s41598-019-42018-y

Patrick, T., Mc Gann Ariell, G., Hermandez, \& Russal, E. W. (2018). Retrieved from www.blood journal.org

Premium Times. (June19, 2018).World sickle cell day: Why disease remain endemic in Nigeria.

Robert, J. T. J. (2006). The interaction of social, behaioural and genetic factors in sickle cell disease. National Academies Press (US).

Robin, R. L., Linda, D. W, \& Victoria, O. (2018). Stigma in adults with sickle cell disease and family members: Scale development and pilot study in the USA and Nigeria. International journal of Africa Nursing sciences, 9, 23-29. https://doi.org/10.1016/j.ijans.2018.06.003

Sharifu, T., Rtah, N., Bashir, M., John, O., Sylvia, K., \& Alimah, K. (2018). Knowledge, perception and practices towards sickle cell disease: a community survey among adults in Lubaga division, Kampala Uganda. $B M C$ Public Health, 18, 561. https://doi.org/10.1186/s12889-018-5496-4

Steinberg, M. H. (1998). Pathophysiology of sickle cell disease. Baillieres Clinical Haematology, 11(1), 163-184. https://doi.org/10.1016/S0950-3536(98)80074-7

Steven, H. Y., Nahed, N., \& Troy, G. (2000). Approach to the Vaso-occlusive Crisis in Adults with Sickle Cell Disease. American Family Physician, 61(5), 1349-1356.Retrieved from https://www.aafp.org/afp/2000/0301/p1349.html

World Health Organisation [WHO]. (2006). Sickle cell anaemia report by secretariat. Fifty-ninth world health assembly a59/9 Provisional agenda item 11.4. Retrieved from: http://apps.who.int/gb/archive/pdf_files/WHA59/A59_9-en.pdf

Yvette, B. (2015). Sickle cell trait and disease: raising awareness. Medical New Today. Retrieved from 
https://www.medicalnewstoday.com/articles/302841.php

\section{Copyrights}

Copyright for this article is retained by the author(s), with first publication rights granted to the journal.

This is an open-access article distributed under the terms and conditions of the Creative Commons Attribution license (http://creativecommons.org/licenses/by/4.0/). 